“Immigration and the Life Course," special issue, Canadian Studies in Population 40, no. 1-2 (2013): 35-56.

\title{
Academic performance and educational pathways of young allophones: A comparative multivariate analysis of Montreal, Toronto, and Vancouver
}

\author{
Jacques Ledent \\ Institut national de la recherche scientifique (Montreal) \\ Jacques.Ledent@ucs.inrs.ca \\ Cheryl Aman \\ Independent Researcher, Vancouver \\ Bruce Garnett \\ School District 36, Surrey \\ Jake Murdoch \\ University of Montreal \\ David Walters \\ University of Guelph \\ Marie McAndrew \\ University of Montreal
}

\begin{abstract}
Using several local and provincial data banks enabling one to follow the schoolprogression of the cohort of students who, in Canada's three main immigration-destination cities, were expected to graduate secondary school in 2004, this article examines the academic performance and educational pathways of those students who at home use a language other the main language of schooling: non-French speakers in Montreal and non-English speakers in Toronto and Vancouver. First, after accounting for differences in characteristics, those students (target group) are shown to succeed better than the remaining students (comparison group), especially in Vancouver. However, within the target group, there appear to be substantial differences in performance between linguistic subgroups, which are far from being similar in all three cities. Second, the individual and contextual factors that influence the academic performance of the students in the target group appear to be similar for some and different for others in the three cities, while presenting some more-or-less large discrepancies with the corresponding factors pertaining to the comparison group. The article concludes with a few policy implications.
\end{abstract}

Keywords: academic performance; high school; non-native speakers; Canadian metropolises.

\section{Résumé}

Au moyen de plusieurs banques de données locales et provinciales permettant de suivre la progression scolaire de la cohorte des étudiants qui, dans les trois principales villes canadiennes réceptrices de l'immigration, étaient censés obtenir leur diplôme d'études secondaires en 2004, cet article examine la performance académique et les carrières scolaires de ces étudiants qui à la maison n'utilisent pas la langue dominante d'instruction: non francophones à Montréal et non anglophones à Toronto et Vancouver. En premier lieu, après contrôle pour les différences de caractéristiques, les non locuteurs de la langue dominante performent mieux que les locuteurs de cette même langue. Mais, parmi les premiers, il existe d'importantes différences entre les différents sous-groupes linguistiques qui sont loin d'être similaires dans les trois villes. En deuxième lieu, les facteurs individuels et contextuels qui influencent la performance académique des non locuteurs de la langue dominante sont similaires, pour les uns, et différents, pour les autres, dans les trois villes, tandis qu'ils présentent des écarts plus ou moins larges avec les facteurs correspondants se rapportant aux locuteurs de la langue dominante. Quelques implications politiques sont offertes en guise de conclusion.

Mots-clés: réussite scolaire; école secondaire; allophones; métropoles canadiennes. 


\section{Introduction}

In a context in which equal opportunity has emerged as a fundamental normative benchmark, schools in modern democratic societies are expected to foster the academic success of a student population that is highly diversified in its abilities and interests as well as its social, linguistic and cultural characteristics (McEwen 1995; Crahay 2000). Indeed, this is a particularly big challenge in Canada. For one thing, our provincial school systems tend to stream students on different educational pathways rather late in the overall schooling process, at least when compared with other countries (CMEC 2003). For another, Canada pursues an active immigration policy, which has many consequences for education.

The number of immigrants entering the country every year - 280,691 in 2010 - has significantly increased over the past 15 years (CIC 2011). These immigrants are coming from more diversified countries, and from many countries whose official language is neither French nor English ${ }^{1}$. The selective nature of Canadian immigration policy also results in an immigrant flux which, in contrast with other societies where immigration is less planned, is less slanted toward the lower social classes (McAndrew 2004).

Discrepancies between expected and achieved educational attainments or pathways among immigrant youth, in particular from different backgrounds, require scrutiny. Indeed, the successful integration of immigrant parents into their new country is often assessed, not so much on the basis of their current situation, but on the basis of the quality of relationships that their children are able to establish with the school system, and most of all, the return they get from it in the longer run.

In this regard, much qualitative research, based on the observation of classrooms and schools or on surveys of teachers, students or parents, points to the fact that the academic integration of first- and even second-generation youth in Canada is not without flaws. This is particularly true for recently arrived students who do not have French or English as their mother tongue and also students who belong to the visible minorities (McAndrew and Cicéri 1997; Beiser et al. 1998; Anisef and Kilbride 2001). However, there is a paucity of large-scale quantitative studies that assess the current state of academic performance and educational pathways of immigrant students in the Canadian context (Anisef et al. 2004).

This paucity can largely be explained by the fact that education falls under 10 different provincial and three territorial authorities. Each has its own educational structures, policies and programs, as well as its own way of collecting educational data. Although these bodies exchange information and cooperate through the Council of Ministers of Education Canada, there has never been a systematic comparative study of their approaches to or their results on the academic integration of immigrant students. At both the provincial and school board levels, the interest in large-scale assessments of academic performance and educational pathways of immigrant or minority students is rather new. ${ }^{2}$

Some national data, collected either regularly or periodically through sampled studies (Statistics Canada 2008; Bussière et al. 2004), have been used to partially fill the gap in our knowledge, but they have shortcomings. When the focus is on final attainments, such as the data collected by Statistics Canada, the result is limited information on the educational pathways that students follow and the specific obstacles they may encounter through their formal mandatory schooling. By contrast, the data collected within the framework of the Program for International Students Achievement (PISA) provide valuable information on the competencies of immigrant students. However, they do not reveal whether students' strengths and weaknesses were conducive to a successful school career, nor do they take into account the fact that a substantial proportion of underprivileged immigrant youth may have dropped out by age 15 when most of the tests are carried out. The contribution of such data to identifying the factors that influence school performance is also rather limited, specifically the factors that influence policy development.

\section{Study design and research questions}

The study on the school achievement of students with an immigrant background from which this article is drawn uses provincial or local data banks relating to three contexts (i.e., Quebec, Ontario, and British Columbia), but the

1. With the exception of Quebec where immigrants with a prior knowledge of French now represent more than 60 per cent of the total influx.

2. With the exception of the Toronto District School Board and to a lesser extent the Ministère de l'Éducation, du Loisir et du Sport du Québec. 
focus is on the three major immigrant-destination cities in Canada: Montreal, Toronto, and Vancouver. ${ }^{3}$ An important advantage of such administrative data banks, one which in fact is rarely used in practice, is to make it possible to adopt a longitudinal perspective - that is, to follow the school pathways, of a group (cohort) of students with similar initial conditions. Here we utilize a cohort of students who entered the first level of secondary school - that is, secondaire 1 in Montreal or grade 9 in the other two cities -- in a given time period. But, to ensure comparability between the school systems of the three cities in which entrance and duration time in secondary school differ, we had to adapt the time period to reflect each site-specific schedule of education. Thus the group under study is made up of the students who were expected to graduate in the three cities in 2004 had they followed the "normal" path. It therefore includes those students who started high school in 1999 in Montreal and Vancouver and in 2000 in Toronto.

Ideally, the data available should enable one to identify the youth with an immigrant background on the basis of two markers: immigration status and ethnicity. However, immigration status which is normally derived from the knowledge of the birthplace of the students and of their parents, can be ascertained in Montreal only, ${ }^{4}$ whereas ethnicity, in one or another of its usual forms (having a particular ethno-cultural origin or belonging to a specific group of visible minorities), is not available in any of the study sites. For this reason, home language, which happens to be collected in all three sites, was selected as the marker of choice to separate the group of students with an immigrant background - the target group for short - from the group of the remaining students - thus the comparison group. ${ }^{5}$

A particularly noteworthy element to consider when picking home language as a marker of immigrant background in the study of educational outcomes is whether the home language is identical to the language of schooling, which prompted us to limit the analysis to those schools in which the language of instruction is the language of the majority - that is, French in Montreal and English in Toronto and Vancouver. ${ }^{6}$ Specifically, the target group consists of those students in the main educational system of each of the three sites who at home use a language other than the language of schooling - that is, non-French speakers in Montreal and non-English speakers in Toronto and Vancouver. Most unfortunately, such a group cannot be labelled in a simple way and thus, in the title of the article, ${ }^{7}$ 'allophones', for lack of a better word, is used to designate it. Although not entirely correct because it leaves aside English speakers in Montreal and French speakers in Toronto and Vancouver who are also members of the target group, such a designation alludes to those students in the target group who actually are of prime interest to us. It in any case, the comparison group comprises those students who at home speak their language of schooling: French in Montreal and English in Toronto and Vancouver.

To be sure, home language presents features that are often common with ethnicity: allophones belong more frequently to the visible minorities, while members of the visible minorities are more often allophones. Home language also intersects with immigration status. First, the target group consists, for the most part, of first-generation students who do not speak at home the language of schooling and of second-generation students who still use the original language of their parents. Second, the comparison group includes a fair proportion of first- and second-generation

3. Geographically, Montreal refers to the three French-language school boards covering the Island of Montreal, Toronto to the Toronto District School Board and Vancouver to a set of 12 centrally located school boards. But whereas Montreal and Vancouver also include the private schools located on the territories thus delimited, Toronto does not include such schools, as well as other schools belonging to a publicly subsidized Catholic sector. Given such territorial differences, the term 'site' rather than 'city' will be used in the remainder of this paper to designate the three spatial entities under study.

4. In Toronto, the birthplace of the students is known, thereby making it possible to identify the first generation, whereas in Vancouver the birthplace of the students and their parents is not available at all.

5. At all three sites, home language stems from the self-declared information given in the student's registration form. But this information does not allow for multiple responses, when in fact some students in the target group and in the comparison group as well are bilingual, if not trilingual in the case of Montreal. In Montreal, for example, many of the students with an origin in Northern Africa who at home speak Arabic more often than French do not indicate Arabic as their home language but rather French to underscore their integration into Quebec society.

6. Whereas in Toronto and Vancouver a small French-language system of education serves few immigrants, whom incidentally can be described as French speakers, Montreal has a somewhat substantial English-language system. But this system primarily serves various communities, including one of British descent that settled long ago. Indeed, its clientele includes few first-generation students and fewer and fewer second-generation students in the wake of the adoption in 1977 of Bill 101 as the cornerstone of Quebec's language policy.

7. Whereas French speakers in the English-language system account for a small proportion of all students in Toronto and Vancouver, English speakers in the French-language system account for about a quarter of all students in Montreal. 
students in Montreal who trace their origins to francophone Europe in Montreal and in the other two sites who trace their origins to the UK, the US and other Anglophone countries.

This article examines academic attainment (graduation) and educational pathways (participation in a course leading to college/university) in the target group and contrasts them with the corresponding elements in the comparison group. More specifically, it answers the following questions:

1. After accounting for differences in characteristics, do the target group and selected linguistic subgroups fare better than the comparison group?

2. What are the factors that significantly influence the academic performance and the educational pathways of the target group?

3. Do these factors affect the comparison group in the same manner?

But while pursuing such an aim, this article places a particular emphasis on the main similarities and differences across the three sites (Montreal, Toronto and Vancouver).

\section{Factors influencing school achievement among the youth of immigrant origin: Main explanations}

Unlike other social categories such as gender or social class, ethnicity ${ }^{8}$ does not have an easily predictable unidirectional relationship with achievement. Even when one specifically focuses on markers associated with migration, Canadian and international literature clearly illustrates the wide variety of educational profiles and experiences that can be associated with various subgroups defined by any of these markers (Marks 2005; OECD 2006).

In societies in which immigration and poverty are closely linked, this complex reality is sometimes masked by the overlapping of the two phenomena, but in contexts such as Canada in which the immigration influx includes a lower proportion in the lower social classes, variability is the norm. ${ }^{9}$ Consequently, identifying the factors that explain the differences in academic achievement and educational pathways among immigrant/minority youth is one of the main objectives of research.

In this regard, there are many explanations, most in agreement although sometimes contested by various authors. Socioeconomic theories stress the close relationship that exists between socioeconomic status and school results, both in the whole school population (Haveman and Wolfe 1994; Bradley and Corwin 2002) and among immigrant students (Portes and Zhou 1993; Portes 1994; Zady and Portes 2001; Zhou and Lee 2007). Poverty which is generally associated with a deficit of cultural capital among families and a lack of active involvement in the educational promotion of their children is identified as the main explanatory factor in school failure. This school of thought also shows the contribution of schooling to the segmented assimilation of different groups of immigrants.

However, other research shows that socioeconomic status does not have the same overwhelming impact on immigrant youth as on the full student body. On the one hand, even among immigrants with a high socio-economic status, the mastery of the language of schooling is a lengthy process. Thus, factors such as age at arrival (Corak 2011) or prior exposure to the host language cannot be overlooked (Collier 1989; Cummins 2000). Linguistic competencies especially have an impact on disciplines with strong linguistic and cultural components such as history and literature. The latter presents greater challenges for students whose first language is not the language of schooling compared with scientific disciplines such as mathematics or physics (Chamot and O’Malley 1994; Duff 2001).

On the other hand, many Canadian and European studies show that underprivileged immigrants or secondgeneration students tend to over-perform when compared with native peers of the same socio-economic background (Toronto Board of Education 1999; Vallet and Caillé 1996; McAndrew 2001). Some explain this phenomenon by suggesting that immigrants represent a sub-sample of individuals who are particularly motivated individuals or who may be subject to family pressures to succeed in order to fulfill the parents' dreams (Zhou and Bankston 2001). Nevertheless, because this migratory effect is inconsistent, a variety of socio-cultural explanations have been invoked.

\footnotetext{
8. Defined here in its sociological sense as a communalization or abscription process, based on the belief of a common or putative ancestry and a variety of markers, such as national origin, immigrant status, language, "race," religion or even caste (Schermerhorn 1970).

9. Which is not to mean that poverty is not to be found among the immigrants living in Canada: see for example, Halli and Kazemipur 2001; Picot and Hou 2003).
} 
Ogbu (Ogbu 1992; Ogbu and Simmons 1998) asserts, as the main factor explaining differences, the existence of a conflictual or a positive relationship with the host society and the integration model it proposes. On the one hand, individuals, most often immigrants who choose to settle in the new country for socioeconomic reasons, are likely to adhere to an ideology of social mobility through schooling and thus consider the obstacles they encounter as temporary. To foster the school success of their children, they are willing to forego their preoccupation for maintaining their linguistic and cultural characteristics, because they essentially hold an instrumental relationship with schooling. On the other hand, individuals belonging to groups whose presence in the host country is the result of a displacement more or less desired may not look at the institutions of the host society in a favourable way and, as a result, may believe that schooling is not really a way out for their children.

Other researchers focus on the characteristics of the home country culture, especially the values that are closely linked with school success, even in our modern school system: conformism, respect for authority, hard work as well as the valorization of the written word (Peng and Wright 1994; Samuel et al. 2001; Chow 2004). In some communities, therefore, ethnicity would be strong cultural capital, generating many practices, both in the family and within the community, that are conducive to school success.

Finally, other studies insist on the importance of systemic factors, such as the reaction of the school system and of specific schools to immigrants in general and to various subgroups (Gillborn and Gipps 1996; Johnson and Acera 1999; Dei 1996). This school of thought is particularly interested in the impact of teacher attitudes and expectations on the success of various students, who are largely influenced by an unstated pecking order reflecting national and international dynamics. It also examines various indicators of institutional discrimination, such as the variance between schools with similar characteristics as well as the early streaming of immigrant students into less prestigious courses.

In this article, we analyse, to varying degrees, many of these systems of explanation but in a non-systematic manner. Indeed, the variables retained in our analysis were not selected on the basis of their theoretical relevance but rather on a practical basis: they had to be available in each of the three data banks used. The strength of this article lies in pre-migratory and linguistic factors as well as in schooling process and school characteristic variables. However, the socioeconomic status indicators are only proxies and, as a result, our capacity to grasp the socio-cultural phenomenon is limited.

Indeed, different factors that could be hidden under the variables of language or region of origin, such as family practices and strategies, values, positive or conflictual relations with schooling, cannot be assessed using our methodology. As for systemic factors, our study provides an extensive set of indicators at a macro or meso level, such as the fact that schools belong to the private or public sector, the extent to which they face an educational challenge, or the concentration of the target group they experience. However, we cannot identify which practices or attitudes explain the differences of results encountered between them.

\section{Descriptive analysis}

Prior to the multivariate analysis that will answer the three research questions stated earlier, we present a short descriptive analysis of the target group, beginning with its numerical importance and composition by linguistic subgroup. $^{10}$

Although the target group is much larger in Vancouver (9,039 students) than in Toronto (6,370 students) and Montreal (4,750 students), its proportion in the total student population is roughly similar in all three sites-ranging from 34.0 per cent in Montreal to 39.8 per cent in Vancouver, with an intermediate value of 37.5 per cent in Toronto (see Table 1). Its linguistic composition, however, differs widely among the three sites, because in each site, it reflects the particular diversity observed locally in terms of the geographical origin of the immigrants who settled there in the last two or three decades. Thus, it is not surprising to see that some of the most populous linguistic subgroups consist of (first-generation) students of the most recent waves, as well as (second-generation) students born to immigrants of earlier waves. The most common languages are: English, ${ }^{11}$ Spanish, and Arabic in Montreal, Chinese and Tamil in Toronto, and Chinese and Punjabi in Vancouver.

10. For a fuller account of this descriptive analysis, see McAndrew et al. 2011.

11. In Montreal, although it is the largest linguistic subgroup, the English subgroup was not retained as a separate linguistic subgroup, because it includes slightly more than one-quarter of students who belong to the third generation or more. 
Table 1. The study population by site.

\begin{tabular}{lrlrlr}
\hline \multicolumn{1}{c}{ Montreal } & \multicolumn{2}{c}{ Toronto } & \multicolumn{2}{c}{ Vancouver } \\
\hline Non-French Speakers & 4,750 & Non-English Speakers & 6,370 & Non-English Speakers & 9,039 \\
English & 753 & Chinese & 1,439 & Chinese & 3,573 \\
Spanish & 718 & Tamil & 600 & Punjabi & 1,332 \\
Arabic & 529 & Russian & 366 & Tagalog & 516 \\
Creole & 359 & Urdu & 360 & Korean & 375 \\
Chinese & 294 & Persian & 293 & Hindi & 368 \\
Russian & 201 & Korean & $n . a$. & Spanish & 363 \\
Vietnamese & 182 & Spanish & 254 & Vietnamese & 358 \\
Armenian & 120 & Vietnamese & 236 & Persian & 319 \\
Portuguese & 119 & Somali & 231 & Russian & 139 \\
Persian & 97 & Punjabi & $n . a$. & Arabic & 114 \\
Tagalog & 96 & Portuguese & 134 & & \\
Romanian & 90 & Arabic & 126 & & 15,034 \\
French speakers & 9,210 & English speakers & 9,649 & English speakers & 24,073 \\
\hline Total & 13,960 & Total & 16,019 & Total &
\end{tabular}

Notes: n.a.=Figures not available. The subgroups not considered in the descriptive analysis are in italics.

\section{Individual and contextual characteristics}

A close examination of Table 2 reveals that the target group differs from the comparison group in a similar way in all three sites, although there are some inconsistencies for some of the variables considered which come in three types: socio-demographic characteristics, schooling process variables, and school context variables.

First, regarding socio-demographic characteristics, in each of the three sites the target group appears to have a comparatively lower status than the comparison group, because it is much more represented in the lowest median family income quintile and, conversely, much less represented in the highest quintile. Moreover, the target group in each site is far from homogeneous. According to data not shown in this article, some linguistic subgroups appear to be much more socio-economically disadvantaged than others. These are most often visible minorities: Creole and Somali speakers in Montreal and Toronto, respectively, and Vietnamese speakers in both Toronto and Vancouver, the latter group showing a very distinct profile across the sites. Also, in Montreal and Toronto (where, unlike Vancouver, birthplace is available) the target group was much more often born outside Canada than the comparison group-a foreseeable result. However, according to data also not shown here, the extent of variation in the proportion of those born outside Canada is huge, ranging in Montreal from 36.8 per cent to 96.5 per cent, respectively, for Vietnamese and Tamil speakers, and in Toronto from 38.2 per cent to 97.3 per cent, respectively, for Portuguese and Somali speakers.

As for schooling process variables, the target group enters high school late more often than the comparison group, only slightly in Vancouver (5.5 per cent v. 3.4 per cent) and Toronto (7.4 per cent v. 5.9 per cent) but somewhat more in Montreal (41.2 per cent v. 20.0 per cent), where about one-quarter of those who arrived late are late by two years or more! Nevertheless, what is interesting here is not so much the variation between groups, but the negative profile of the full Montreal cohort, for both French and non-French speakers. As we will see later, this negativity is also reflected in graduation rate- which would tend to indicate that a structural effect linked to the functioning of the school system in Montreal (or in the province of Quebec) is at stake here.

At no site does the target group change school more often than the comparison group. However, it obviously receives services in the language of instruction (soutien linguistique in Montreal or ESL/ESD courses in Toronto and Vancouver) much more often during secondary school. Although Montreal and Toronto have a similar percentage of target group students requiring such services (19.5 per cent and 19.1 per cent, respectively), the variation is greater in Montreal, whereas a given linguistic subgroup does not show the same level of need in the two sites. After all, immigrant groups are more or less linguistically close or familiar with French or English. As for Vancouver, its rate of ESL/ESD students is higher (28 per cent), and the range is similar to that of Toronto.

In terms of the contextual variables, the target group in all three sites has a rate of concentration, in schools in which it represents the majority, that is higher than that of the comparison group. Montreal emerges as the site where 
Ledent et al.: Academic performance and educational pathways of young allophones

Table 2. Characteristics of the target and comparison groups.

\begin{tabular}{|c|c|c|c|c|c|c|c|c|}
\hline \multirow[b]{2}{*}{ Type } & \multirow[b]{2}{*}{ Variable } & \multirow[b]{2}{*}{ Characteristic } & \multicolumn{2}{|c|}{ Montreal } & \multicolumn{2}{|c|}{ Toronto } & \multicolumn{2}{|c|}{ Vancouver } \\
\hline & & & $\begin{array}{c}\text { Non French } \\
\text { speakers }\end{array}$ & $\begin{array}{c}\text { French } \\
\text { speakers }\end{array}$ & $\begin{array}{l}\text { Non English } \\
\text { speakers }\end{array}$ & $\begin{array}{l}\text { English } \\
\text { speakers }\end{array}$ & $\begin{array}{l}\text { Non English } \\
\text { speakers }\end{array}$ & $\begin{array}{l}\text { English } \\
\text { speakers }\end{array}$ \\
\hline \multirow{4}{*}{$\begin{array}{l}\text { Socio- } \\
\text { demographic } \\
\text { variables }\end{array}$} & Gender & $\%$ female & 49.0 & 49.6 & 47.7 & 48.4 & 48.6 & 48.1 \\
\hline & $\begin{array}{l}\text { Median family } \\
\text { income }\end{array}$ & $\begin{array}{l}\% \text { in lowest } \\
\text { quintile }\end{array}$ & 30.3 & 14.7 & 26.7 & 14.9 & 30.8 & 13.3 \\
\hline & & $\begin{array}{l}\% \text { in highest } \\
\text { quintile }\end{array}$ & 14.0 & 23.0 & 10.5 & 26.9 & 11.3 & 24.9 \\
\hline & Birthplace* & $\begin{array}{l}\% \text { born outside } \\
\text { Canada }\end{array}$ & 60.9 & 10.1 & 73.8 & 15.7 & & \\
\hline \multirow{5}{*}{$\begin{array}{l}\text { Schooling } \\
\text { process } \\
\text { variables }\end{array}$} & Age upon entry & $\%$ early / on time & 58.8 & 80.0 & 92.6 & 94.1 & 94.5 & 94.2 \\
\hline & & $\%$ late by $2+$ yrs & 11.2 & 1.3 & 0.0 & 0.0 & 0.1 & 0.1 \\
\hline & Changed school & $\%$ yes & 33.7 & 33.7 & 19.4 & 19.3 & 39.3 & 38.5 \\
\hline & $\begin{array}{l}\text { Services in language } \\
\text { of instruction }\end{array}$ & $\%$ yes & 19.5 & 0.1 & 19.1 & 2.1 & 27.9 & 0 \\
\hline & $\begin{array}{l}\text { Level of entry in } \\
\text { jurisdiction }\end{array}$ & $\begin{array}{l}\% \text { in } 1 \text { st year of } \\
\text { secondary }\end{array}$ & 19.3 & 10.8 & 20.4 & 18.4 & 6.8 & 3.0 \\
\hline \multirow[t]{4}{*}{$\begin{array}{l}\text { School context } \\
\text { variables }\end{array}$} & $\begin{array}{l}\text { Attendance at a } \\
\text { socioeconomically } \\
\text { challenged school in } \\
\text { public sector }\end{array}$ & $\%$ yes & 61.3 & 58.1 & 39.9 & 24.8 & 42.4 & 21.0 \\
\hline & $\begin{array}{l}\text { Attendance at a } \\
\text { private school } * *\end{array}$ & $\%$ yes & 22.3 & 36.2 & & & 9.3 & 11.9 \\
\hline & Concentration of & $\%$ in $0-25$ & 19.8 & 62.4 & 5.3 & 17.2 & 22.1 & 49.2 \\
\hline & $\begin{array}{l}\text { target group in } \\
\text { school attended }\end{array}$ & $\%$ in $76-100$ & 20.5 & 1.4 & 17.5 & 8.0 & 12.2 & 1.0 \\
\hline
\end{tabular}

Notes: *Not available in Vancouver; **Not available in Toronto.

school segregation between the target and comparison groups is the highest. In the other sites, a significant percentage of English speakers attend such concentration schools, which is not the case for French speakers in Montreal. As expected, concentration in schools in which the target group represents more than 75 per cent of the population is also very different between linguistic subgroups. For example, according to data again not shown here, Montreal's figures range from 2.2 per cent for Creole speakers to 35.1 per cent for Persian speakers; Toronto's range from 0.9 per cent for Vietnamese speakers to 27.3 per cent for Arabic speakers; and Vancouver's range from 2.0 per cent for Persian speakers to 29.0 per cent for Vietnamese speakers.

As could be expected from a comparatively lower median family income, private school attendance is lower, although only slightly, for the target group than the comparison group in Montreal and Vancouver where these data are available. Because of the generous funding allocated to private schools in Montreal, the proportion of students who attend private school is much higher there than in Vancouver for both the target and comparison groups. Nevertheless, the variation among linguistic subgroups is high. Particularly fascinating are the positions on the continuum of both Vietnamese and Tagalog subgroups, which are totally opposite of each other in Montreal and in Vancouver. This observation, as well as others on "same-group" variations across sites, points to the need to better understand what may be hidden beneath the language label. Could it be a reflection of differing birthplaces or ethnic origins in the source country?

In summary, a trend that clearly emerges from the three sites is the fact that, in contrast to the comparison group, the target group is somewhat less positive in terms of the sociodemographic, schooling process, and school context variables considered here, both within and across the three sites. Thus, as a whole, the target group possesses a profile that could perhaps lead one to expect potential problems in terms of schooling experience and outcomes.

\section{Indicators of academic performance and educational pathways}

Two variables are used to describe the educational experience of the students under study. The first variablegraduation rate two years after the expected year-expresses academic performance. And because graduating from a secondary school is one thing and aspiring to a postsecondary education is another, the second variable-rate of par- 
"Immigration and the Life Course," special issue, Canadian Studies in Population 40, no. 1-2 (2013)

Table 3. Cumulative graduation rate (\%): Target group by subgroup and comparison group.

\begin{tabular}{llcccc}
\hline \multicolumn{1}{c}{ Montreal } & \multicolumn{2}{c}{ Toronto } & \multicolumn{2}{c}{ Vancouver } \\
\hline \multicolumn{1}{c}{ Subgroup } & Rate & Subgroup & Rate & Subgroup & Rate \\
\hline Non French Speakers & 62.4 & Non English Speakers & 64.5 & Non English Speakers & 81 \\
Spanish & 53.2 & Chinese & 78.1 & Chinese & 89 \\
Arabic & 70.7 & Tamil & 71.9 & Punjabi & 85 \\
Creole & 40.5 & Urdu & 60.0 & Tagalog & 79 \\
Chinese & 80.6 & Russian & 63.6 & Hindi & 71 \\
Vietnamese & 84.1 & Persian & 51.5 & Korean & 81 \\
Portuguese & 52.9 & Spanish & 46.9 & Spanish & 61 \\
Persian & 66.0 & Vietnamese & 62.3 & Vietnamese & 68 \\
Tagalog & 57.3 & Arabic & 53.6 & Persian & 75 \\
Romanian & 84.4 & Portuguese & 47.3 & Russian & 73 \\
Tamil & 50.6 & Somali & 49.6 & Arabic & 73 \\
French Speakers & 66.3 & English Speakers & 64.8 & English Speakers & 78 \\
\hline
\end{tabular}

Note: Graduation in province for Montreal and Vancouver but in jurisdiction for Toronto.

ticipation in a selective or university-bound course ${ }^{12}$-is designed to ascertain the probability that the same students are preparing for future postsecondary education. ${ }^{13}$

Overall, as can be seen in Table 3, students in the target group graduate more or less like those in the comparison group. Somewhat lower in Montreal (62.4 per cent v. 66.3 per cent), the cumulative graduation rate is similar in Toronto (64.5 per cent v. 64.8 per cent) and slightly higher in Vancouver (81 per cent v. 78 per cent). But in all three sites, there are notable differences among the various linguistic subgroups that appear to be wider in Montreal (between 40.5 per cent for Creole speakers and 84.4 per cent for Romanian speakers) than in Toronto (between 46.9 per cent for Spanish speakers and 78.1 per cent for Chinese speakers) and especially Vancouver (between 61 per cent for Spanish speakers and 89 per cent for Chinese speakers).

Moreover, although some linguistic subgroups present a relative performance that is consistent in all three sites (such as the high-achieving Chinese speakers and the low-achieving Spanish speakers), other linguistic subgroups perform differently depending on the site, as exemplified by Vietnamese speakers-who are a high-achieving subgroup in Montreal, an about-average subgroup in Toronto, and a low-achieving subgroup in Vancouver. However, black minority students (Creole speakers in Montreal and Somali students in Toronto) tend to be at risk, just like Portuguese speakers-at least, in Montreal and Toronto.

Data regarding participation in selective or university-bound courses reveal that such participation is higher in the target group than in the comparison group, but the difference between the two groups is substantially higher in Vancouver (54 per cent v. 28 per cent) than in Toronto (55.8 per cent v. 39.8 per cent) and especially Montreal (32.9 per cent v. 31.9 per cent; see Table 4). Here too, in each site there appear to be wide variations in the participation of the various linguistic subgroups, but this time they are only marginally wider in Montreal (between 6.4 per cent for Creole speakers and 67.3 per cent for Chinese speakers) than in Toronto (between 19.4 per cent for Portuguese speakers and 76.7 per cent for Chinese speakers) and Vancouver (between 19 per cent for Spanish speakers and 77 per cent for Chinese speakers).

In other words, the intercity differences just observed resemble those observed for graduation, except that compared to the students in the comparison group, those in the target group tend to do better with respect to participation than graduation — at all three sites. Moreover, intra-city differences are similar to those observed previously, with a notable exception in Vancouver, where the high-achieving Punjabi and Tagalog subgroups (in terms of cumulative graduation rates) have a rate of participation in a selective or university-bound course that is lower than that of English speakers.

12. In Montreal, participation in three courses (mathematics, physics, and chemistry) is needed to pursue a CEGEP program in the natural or health sciences. In Toronto, it is participation in any grade 12 university-bound courses in maths, English, or science. And finally, in Vancouver, it is participation in the course Principles of Maths 12.

13. In Quebec, unlike the rest of Canada, students do not move directly from secondary school to university. Rather, they have to transit through a college (CEGEP) where they spend two years pursuing a specific program in pure and applied sciences, health sciences, or social sciences that prepares them for university. 
Ledent et al.: Academic performance and educational pathways of young allophones

Table 4. Participation rate (\%) in a selective or university-bound course: Target group by sugbroup and comparison group.

\begin{tabular}{llcccc}
\hline \multicolumn{1}{c}{ Montreal } & \multicolumn{2}{c}{ Toronto } & \multicolumn{2}{c}{ Vancouver } \\
\hline \multicolumn{1}{c}{ Subgroup } & Rate & Subgroup & Rate & Subgroup & Rate \\
\hline Non French Speakers & 32.4 & Non English Speakers & 55.8 & Non English Speakers & 54 \\
Spanish & 18.2 & Chinese & 76.7 & Chinese & 77 \\
Arabic & 41.8 & Tamil & 67.0 & Punjabi & 37 \\
Creole & 6.4 & Urdu & 54.7 & Tagalog & 36 \\
Chinese & 67.3 & Russian & 60.4 & Hindi & 22 \\
Vietnamese & 63.2 & Persian & 42.7 & Korean & 68 \\
Portuguese & 16.8 & Spanish & 22.0 & Spanish & 19 \\
Persian & 32.0 & Vietnamese & 52.5 & Vietnamese & 41 \\
Tagalog & 13.5 & Arabic & 46.0 & Persian & 47 \\
Romanian & 60.0 & Portuguese & 19.4 & Russian & 55 \\
Tamil & 23.5 & Somali & 30.3 & Arabic & 39 \\
French Speakers & 31.9 & English Speakers & 39.8 & English Speakers & 28 \\
\hline
\end{tabular}

Note: Graduation in province for Montreal and Vancouver but in jurisdiction for Toronto.

In brief, the various trends established from our descriptive analysis appear to concur with the explanations underpinning two of the main strands of literature mentioned earlier in section 4 - on the one hand, a global positive impact of migration on educational aspirations and resilience, and on the other hand, a clear mitigating effect of cultural factors, for which our linguistic subgroup variable is a proxy.

\section{Multivariate analysis (I): Graduation}

Undoubtedly, comparison of the graduation and participation indicators between the target group (and its various linguistic subgroups) and the comparison group is affected by the composition of the various subgroups in terms of their individual and contextual characteristics. Thus, the exposition shifts to a multivariate analysis, expected to reveal the true differences between the various subgroups by controlling for their characteristics and, in a second step, to assess the impact of these characteristics on the two indicators pertaining to the target and comparison groups.

The multivariate analysis consists of two parts. In the first part, graduation serves as the dependent variable, whereas in the second, participation in a selective or university-bound course serves that role. In both cases, the independent variables include a variable representative of the subgroups concerned as well as 10 variables closely linked to the 10 characteristics examined earlier in the descriptive analysis, ${ }^{14}$ which are used here as control variables:

- three sociodemographic variables: gender, median family income, and birthplace;

- four variables linked to the schooling process: age upon entry, school change, services in the language of instruction (ESL/ESD or soutien linguistique received during secondary schooling), and entry level;

- three contextual variables: attendance at a private school, attendance at a public school identified as socioeconomically challenged, and concentration of the target group in the school attended.

Precise definitions of these independent variables appear in Table 5.

Because the available information is on the students as well as the schools which they attend, the multivariate statistical analysis of each of the two dependent variables employs a multilevel model in which the students (level 1) are nested within the schools (level 2). Specifically, in regressing the two dependent variables-which happen to be categorical (yes/no) and not continuous - on the level 1 and level 2 predictors, we use a mixed logit model. Such a model falls in the category of hierarchical generalized linear models in which the dependent variable follows a Bernoulli (0/1) distribution, and the response of the dependent variables to the various predictors of both levels is

14. Only nine variables were used in the case of Toronto, because there are no private schools in the Toronto District School Board as well as Vancouver, where birthplace is not available. 
Table 5. Multivariate analysis: The control variables.

\begin{tabular}{|c|c|c|c|}
\hline Type & Variable & Reference value & Other value(s) \\
\hline \multirow{3}{*}{$\begin{array}{l}\text { Socio- } \\
\text { demographic } \\
\text { variables }\end{array}$} & Gender & Male & Female \\
\hline & Median family income (\$) & Continuous variable & \\
\hline & Birthplace* & Canada & Outside Canada \\
\hline \multirow{4}{*}{$\begin{array}{l}\text { Schooling } \\
\text { process } \\
\text { variables }\end{array}$} & Age upon entry & Early / On time & Late \\
\hline & Changed school & No & Yes \\
\hline & $\begin{array}{l}\text { Services in language of } \\
\text { instruction }\end{array}$ & No & Yes \\
\hline & Entry level in jurisdiction & Primary & 1st year of secondary \\
\hline \multirow[t]{3}{*}{$\begin{array}{l}\text { School } \\
\text { context } \\
\text { variables }\end{array}$} & $\begin{array}{l}\text { Attendance at a } \\
\text { socioeconomically challenged } \\
\text { school in public sector }\end{array}$ & No & Yes \\
\hline & Attendance at a private school** & No & Yes \\
\hline & $\begin{array}{l}\text { Concentration of target group } \\
\text { in school attended }(\%)\end{array}$ & $0-25$ & $26-50,51-75,76-100$ \\
\hline
\end{tabular}

Notes: *Not available in Vancouver; **Not available in Toronto.

mapped by means of a logit link. ${ }^{15}$ In practice, its estimation was made using the MIXED procedure available in the SAS software application (SAS 2008). ${ }^{16}$

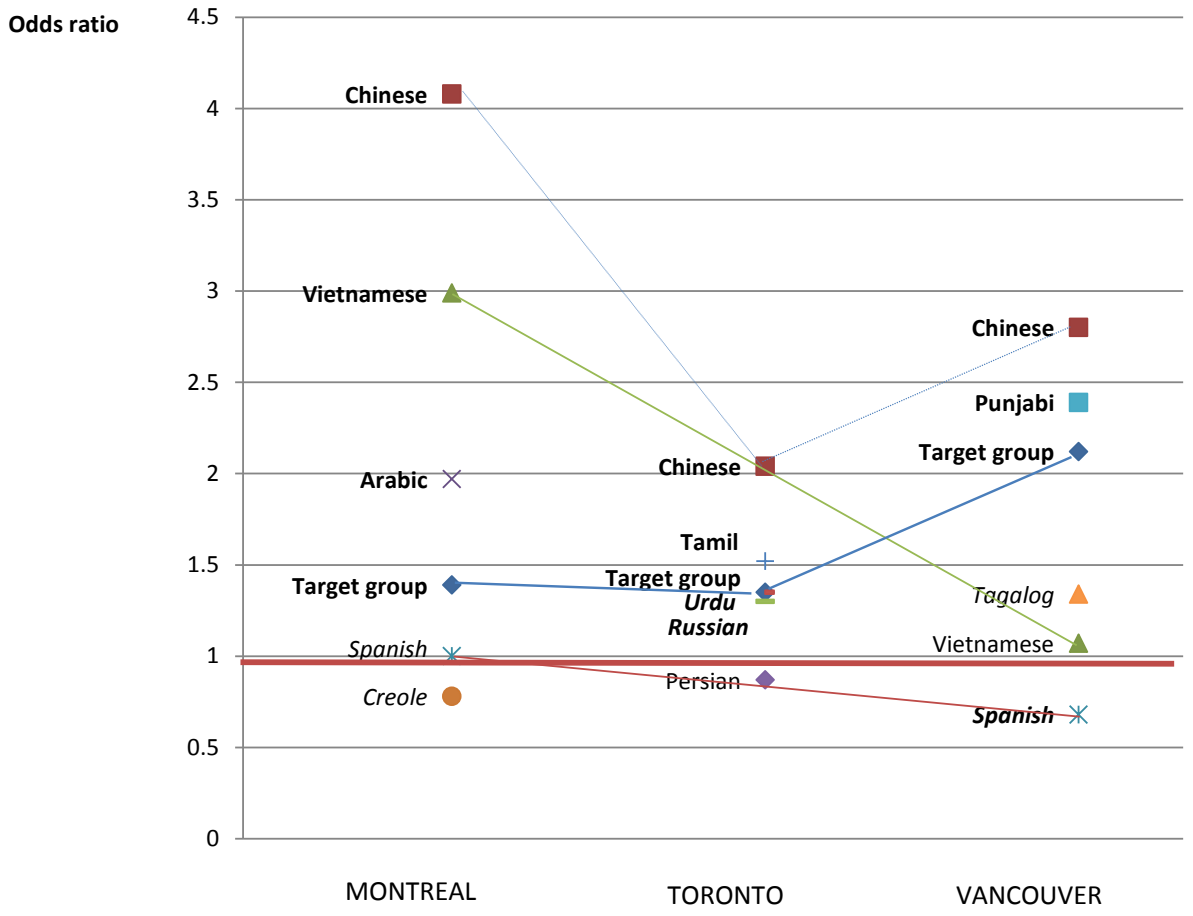

Figure 1. Odds of graduation: Target group and its linguistic subgroups v. comparison group.

Note: subgroups significant at $<0.001$ are in bold, those significant at $<0.05$ are in bold italics, and those significant at $<0.1$ are in italics.

15. Using such an approach, it is impossible to evaluate the variance attributed to specific groups of individual factors (e.g., socio-demographic, schooling process, contextual). But it is possible to identify the percentage of total variation at the school level, which is explained by differences in the students received, at least for the variables included in the model. In the various tables presenting our estimated models, these statistics are presented as a proxy for the impact as a whole of the individual variables included on the right-hand side.

16. It should be noted that the intercept includes not only a fixed part but also a random part with a zero mean and a variance $(\mathrm{s} 2 \mathrm{u})$, which is established within the estimation procedure. 
Table 6. Odds of graduation: Odds ratios of target subgroup(s) v. comparison group.

\begin{tabular}{|c|c|c|c|c|c|c|c|}
\hline \multirow{2}{*}{ Site } & \multirow{2}{*}{ Subgroup } & \multirow{2}{*}{$\begin{array}{l}\text { Global } \\
\text { odds } \\
\text { ratio }^{\mathrm{a}}\end{array}$} & \multirow{2}{*}{$\begin{array}{c}\begin{array}{c}\text { Models w/o } \\
\text { control }\end{array} \\
\text { Odds ratio }\end{array}$} & \multirow{2}{*}{$\begin{array}{c}\begin{array}{c}\text { Models w/ } \\
\text { control }\end{array} \\
\text { Odds ratio }\end{array}$} & \multicolumn{2}{|c|}{ Intraclass correlation } & \multirow{2}{*}{$\begin{array}{c}\% \text { of school } \\
\text { variance } \\
\text { explained } \\
\text { by model }\end{array}$} \\
\hline & & & & & $\begin{array}{l}\text { Empty } \\
\text { model }\end{array}$ & $\begin{array}{l}\text { Models w } \\
\text { control }\end{array}$ & \\
\hline $\begin{array}{l}\text { Montreal } \\
(\mathrm{N}=13,960)\end{array}$ & Non French speakers & 0.84 & 1.08 & $1.39 * * *$ & $53.7 \%$ & $33.4 \%$ & $37.7 \%$ \\
\hline & $\begin{array}{l}\text { Subgroups } \\
\text { Spanish } \\
\text { Arabic } \\
\text { Creole } \\
\text { Vietnamese } \\
\text { Chinese } \\
\text { Other non French speakers }\end{array}$ & $\begin{array}{l}0.58 \\
1.23 \\
0.35 \\
2.69 \\
2.11 \\
\text { n.c. }\end{array}$ & $\begin{array}{l}0.87 \\
1.62 * * * \\
0.52 * * * \\
2.78 * * * \\
2.70 * * * \\
1.07\end{array}$ & $\begin{array}{l}1.00 \\
1.97 * * * \\
0.78 * \\
2.99 * * * \\
4.08 * * * \\
1.40 * * *\end{array}$ & & $33.5 \%$ & $37.6 \%$ \\
\hline $\begin{array}{l}\text { Toronto } \\
(\mathrm{N}=16,233)\end{array}$ & $\begin{array}{l}\text { Non English speakers } \\
\text { Subgroups } \\
\text { Chinese } \\
\text { Tamil } \\
\text { Urdu } \\
\text { Russian } \\
\text { Persian } \\
\text { Other non English speakers }\end{array}$ & $\begin{array}{l}1.94 \\
1.39 \\
0.81 \\
0.95 \\
0.58 \\
\text { n.c. }\end{array}$ & $\begin{array}{l}2.08 * * * \\
1.52 * * * \\
1.35 * * * \\
1.30 \\
0.73 * \\
0.84 *\end{array}$ & $\begin{array}{l}2.04 * * * \\
1.68 * * * \\
1.57 * * \\
1.54 * * \\
0.87 \\
0.90\end{array}$ & $13.0 \%$ & $9.0 \%$ & $\begin{array}{l}30.7 \% \\
30.7 \%\end{array}$ \\
\hline $\begin{array}{l}\text { Vancouver } \\
(\mathrm{N}=24,248)\end{array}$ & $\begin{array}{l}\text { Non English speakers } \\
\text { Subgroups } \\
\text { Chinese } \\
\text { Punjabi } \\
\text { Vietnamese } \\
\text { Tagalog } \\
\text { Spanish } \\
\text { Other non English speakers }\end{array}$ & $\begin{array}{l}2.28 \\
1.60 \\
0.60 \\
1.06 \\
0.44 \\
\text { n. c. }\end{array}$ & $\begin{array}{l}2.90 * * * \\
2.03 * * * \\
0.68 * * * \\
1.22 \\
0.46 * * * \\
1.03\end{array}$ & $\begin{array}{l}2.80 * * * \\
2.39 * * * \\
1.07 \\
1.34 * \\
0.68 * * \\
1.28 * *\end{array}$ & $18.6 \%$ & $\begin{array}{l}17.5 \% \\
19.3 \%\end{array}$ & $\begin{array}{l}5.7 \% \\
0 \%\end{array}$ \\
\hline
\end{tabular}

Notes: $* * *$ Significant at $<0.001 ; * *$ Significant at $<0.05 ; *$ Significant at $<0.10$; n.c. $=$ Not calculated.

${ }^{\text {a }}$ Calculated from corresponding cumulative graduations rates.

\section{Graduation differences between the target and comparison groups}

We first explore whether the target group and its linguistic subgroups ${ }^{17}$ succeed better, all things being equal, than the comparison group. For each site separately, this is done by isolating, from the regression model estimated on the basis of the full student body, the impact of belonging, first, to the target group, and second, to the various linguistic subgroups (see the columns appearing in Table 6 under 'Models w/control'). ${ }^{18}$

In each site, the target group clearly succeeds better in terms of graduation than the comparison group, especially in Vancouver, for which the odds ratio of the former versus the latter is 2.12 (compared to 1.39 in Montreal and 1.35 in Toronto). Differences between the linguistic subgroups are substantial (see also Fig. 1), with the Chinese subgroup outperforming the other subgroups at all three sites (with odds ratios of 4.08 in Montreal, 2.04 in Toronto and 2.80 in Vancouver), and the Vietnamese subgroup behaving differently in Montreal and Vancouver (with odd ratios of 2.99 and 1.07, respectively). Such differences can be interpreted as confirming either the impact of different family and community values and strategies, positive/negative relationships with the host society, or systemic factors such as the teacher's attitude or valorization of specific languages and cultures.

17. Limited here to five, because of statistical requirements regarding minimal size, so that one subgroup only (Chinese speakers) is considered in all three sites, and two others (Spanish and Vietnamese speakers) in just two sites (Montreal and Toronto).

18. The columns appearing in the same table under 'Models w/o control' give the corresponding results obtained without inclusion of the control variables. 
Table 7. Odds of graduation: Impact of factors on target group.

\begin{tabular}{|c|c|c|c|c|c|}
\hline \multirow[t]{2}{*}{ Type } & \multirow[t]{2}{*}{ Variables (ref. value) } & \multirow[t]{2}{*}{ Value } & $\begin{array}{l}\text { Montreal } \\
(\mathrm{N}=4,750)\end{array}$ & $\begin{array}{c}\text { Toronto } \\
(\mathrm{N}=6,370)\end{array}$ & $\begin{array}{l}\text { Vancouver } \\
(\mathrm{N}=9,001)\end{array}$ \\
\hline & & & Odds ratio & Odds ratio & Odds ratio \\
\hline \multirow{3}{*}{$\begin{array}{l}\text { Socio- } \\
\text { demographic } \\
\text { variables }\end{array}$} & Gender (Male) & Female & $1.68 * * *$ & $1.91 * * *$ & $1.64 * * *$ \\
\hline & Median family income & & 1.00 & $1.01 * * *$ & 1.00 \\
\hline & Birthplace (Canada) & $\begin{array}{l}\text { Outside } \\
\text { Canada }\end{array}$ & 1.11 & $1.32 *$ & n.a. \\
\hline \multirow{4}{*}{$\begin{array}{l}\text { Schooling } \\
\text { process } \\
\text { variables }\end{array}$} & $\begin{array}{l}\text { Age upon entry (Early } \\
\text { / On time) }\end{array}$ & Late & $0.39 * * *$ & $0.37 * * *$ & $0.36^{* *}$ \\
\hline & Changed school (No) & Yes & $0.67 * * *$ & $0.33 * * *$ & $0.27 * *$ \\
\hline & $\begin{array}{l}\text { Services in language } \\
\text { of instruction (No) }\end{array}$ & Yes & $0.50 * * *$ & $0.67 * * *$ & 0.88 \\
\hline & $\begin{array}{l}\text { Entry level in } \\
\text { jurisdiction (Primary) }\end{array}$ & $\begin{array}{l}\text { 1st year of } \\
\text { secondary }\end{array}$ & 0.96 & 0.88 & $0.74 * * *$ \\
\hline \multirow[t]{5}{*}{$\begin{array}{l}\text { School } \\
\text { context } \\
\text { variables }\end{array}$} & $\begin{array}{l}\text { Attendance at a } \\
\text { socioeconomically } \\
\text { challenged school in } \\
\text { public sector (No) }\end{array}$ & Yes & 0.93 & 0.71 & $0.79 * *$ \\
\hline & $\begin{array}{l}\text { Attendance at a private } \\
\text { school (No) }\end{array}$ & Yes & $3.24 * * *$ & n.a. & $2.75 * *$ \\
\hline & Concentration of & $26-50 \%$ & 0.98 & 1.24 & 1.19 \\
\hline & target group in school & $51-75 \%$ & 0.99 & 1.21 & 0.83 \\
\hline & attended $\quad(0-25 \%)$ & $76-100 \%$ & $0.51 * *$ & $1.95^{*}$ & $0.51 *$ \\
\hline \multicolumn{3}{|c|}{ Variance of random intercept $\mathrm{s} 2 \mathrm{u}$} & $0.79 * * *$ & $0.16^{* * *}$ & $0.81 * * *$ \\
\hline \multicolumn{3}{|c|}{ Intra-class correlation (empty model) } & $40.5 \%$ & $11 \%$ & $15.4 \%$ \\
\hline \multicolumn{3}{|c|}{ Intra-class correlation (full model) } & $19.4 \%$ & $5 \%$ & $19.8 \%$ \\
\hline \multicolumn{3}{|c|}{ Percentage of school variance explained by model } & $52.0 \%$ & $54.5 \%$ & $0 \%$ \\
\hline
\end{tabular}

Notes: ***Significant at $<0.001 ; * *$ Significant at $<0.05$; $*$ Significant at $<0.10 ;$ n.a. $=$ Not available.

\section{Impact of the factors on graduation of the target group}

We now turn to identifying the factors that influence the achievements of the target group. The global impact of individual and contextual variables is assessed first. The relevance of this assessment is twofold. On the one hand, as seen earlier, other studies show that some factors, such as socioeconomic status, have less explanatory power for some immigrant groups than for the full population. On the other hand, if all the groups share many factors, this would point to the relevance of mainstream and generic policies and programs in answering the needs of our target group (and vice versa).

Leaving aside the concentration of the target group in the school attended, ${ }^{19}$ the other nine factors of influence affect graduation in a common direction in the three sites (see Table 7). Their effects, however, are consistently significant in only four cases. Two of those cases concern a factor having a positive effect: being a female (rather than a male) and attending a private (rather than a public) school, as would be expected from the international literature and public perceptions. By contrast, the other two cases relate to factors having a negative effect: arriving late (rather than early or on time) and changing school (rather than not), as often suggested by decision-makers, parents, communities and academics.

In the remaining five cases, the effect of the influence factor appears to be not significant in one site (birthplace and services in the language of instruction) or even two sites (income, level of entry in the school system, and attending a school that is socioeconomically challenged). Undoubtedly, the fact that the impact of median family income is not significant in Montreal and in Vancouver but is significant in Toronto is in line with the literature described earlier, thereby pointing to higher discrepancies that exist among immigrant communities between their current socioeconomic position and their actual cultural and educational capital, largely influenced by their status

19. In the estimated regression pertinent here as well the others to come, this variable tends to yield largely incoherent results, and thus it will not be subject to comment in this article. 
Table 8. Odds of graduation: Impact of factors on comparison group.

\begin{tabular}{|c|c|c|c|c|c|}
\hline \multirow[t]{2}{*}{ Type } & \multirow[t]{2}{*}{ Variables (ref. value) } & \multirow[t]{2}{*}{ Value } & $\begin{array}{l}\text { Montreal } \\
(\mathrm{N}=9,210)\end{array}$ & $\begin{array}{c}\text { Toronto } \\
(\mathrm{N}=9,827)\end{array}$ & $\begin{array}{c}\text { Vancouver } \\
(\mathrm{N}=15,247)\end{array}$ \\
\hline & & & Odds ratio & Odds ratio & Odds ratio \\
\hline \multirow{3}{*}{$\begin{array}{l}\text { Socio- } \\
\text { demographic } \\
\text { variables }\end{array}$} & Gender (Male) & Female & $1.81 * * *$ & $1.41 * * *$ & $1.73 * * *$ \\
\hline & Median family income & & $1.01 * * *$ & $1.01 * * *$ & $1.01 * * *$ \\
\hline & Birthplace (Canada) & $\begin{array}{l}\text { Outside } \\
\text { Canada }\end{array}$ & $1.58 * * *$ & $0.84 * *$ & n.a. \\
\hline \multirow{4}{*}{$\begin{array}{l}\text { Schooling } \\
\text { process } \\
\text { variables }\end{array}$} & $\begin{array}{l}\text { Age upon entry (Early } \\
\text { / On time) }\end{array}$ & Late & $0.17 * * *$ & $0.30 * * *$ & $0.20 * * *$ \\
\hline & Changed school (No) & Yes & $0.29 * * *$ & $0.34 * * *$ & $0.27 * * *$ \\
\hline & $\begin{array}{l}\text { Services in language } \\
\text { of instruction (No) }\end{array}$ & Yes & 0.52 & $1.24 *$ & 1.04 \\
\hline & $\begin{array}{l}\text { Entry level in } \\
\text { jurisdiction (Primary) }\end{array}$ & $\begin{array}{l}\text { 1st year of } \\
\text { secondary }\end{array}$ & 0.82 & $0.73 * * *$ & 0.32 \\
\hline \multirow[t]{5}{*}{$\begin{array}{l}\text { School } \\
\text { context } \\
\text { variables }\end{array}$} & $\begin{array}{l}\text { Attendance at a } \\
\text { socioeconomically } \\
\text { challenged school in } \\
\text { public sector (No) }\end{array}$ & Yes & $0.46^{*}$ & $0.51 * * *$ & 1.03 \\
\hline & $\begin{array}{l}\text { Attendance at a private } \\
\text { school (No) }\end{array}$ & Yes & $2.04 *$ & n.a. & 3.93 \\
\hline & Concentration of & $26-50 \%$ & 1.59 & 1.20 & $1.21 * * *$ \\
\hline & target group in school & $51-75 \%$ & 2.06 & 1.24 & $0.84 * *$ \\
\hline & attended $(0-25 \%)$ & $76-100 \%$ & 2.19 & $2.21 * * *$ & 0.87 \\
\hline \multicolumn{3}{|c|}{ Variance of random intercept $\mathrm{s} 2 \mathrm{u}$} & $1.78 * * *$ & $0.59 * * *$ & 0.28 \\
\hline \multicolumn{3}{|c|}{ Intra-class correlation (empty model) } & $54.5 \%$ & $17 \%$ & $13.6 \%$ \\
\hline \multicolumn{3}{|c|}{ Intra-class correlation (full model) } & $35.1 \%$ & $19 \%$ & $7.8 \%$ \\
\hline \multicolumn{3}{|c|}{ Percentage of school variance explained by model } & $35.7 \%$ & $41.1 \%$ & $42.8 \%$ \\
\hline
\end{tabular}

Notes: $* * *$ Significant at $<0.001 ; *$ Significant at $<0.05 ; *$ Significant at $<0.10 ;$ n.a. $=$ Not available.

in the country of origin. But it could also be linked to the limitations of our indicator, which does not measure the median income of the students' families but rather the median family income in the enumeration area in which they live. By contrast, the fact that non-French speakers do not seem to be affected by attending a school identified as socioeconomically challenged in Montreal, whereas non-English speakers are affected in Vancouver, is more difficult to comprehend, although it could be linked to the fact that, as noted earlier, such schools are actually the norm in Montreal (as the indicator is defined on a Quebec-wide basis) but represent a much more limited sample of the 12 school boards studied in Vancouver. Finally, the remaining three inconsistent factors across sites (birthplace, level of entry, level and services in the language of instruction) point to the great variability of dynamics and cases that can be hidden by such variables, whose identification is clearly beyond the scope of this general conclusion. Nevertheless, for policymakers this finding is interesting because it shows that none of these three characteristics is a clear predictor, on a pan-Canadian basis, of a negative educational experience.

\section{Impact of factors on graduation: Target versus comparison groups}

Broadly speaking, the effects of the factors of influence on graduation of the target group also apply, to some extent, to the comparison group. This time, six rather than all nine of the factors of influence affect graduation in a common direction at all three sites (see Table 8). First, the four factors of influence previously found to be consistently significant for the target group remain here. Particularly noteworthy is the fact that two of those factors (age on arrival and changing schools) have at all three sites a substantially larger impact on the comparison group than on the target group, which probably means that the rationale behind these two schooling process factors is not the same for the two groups. We surmise that for the target group, such a rationale is associated with pre-migratory factors and the time needed to adjust to the host country, whereas for the comparison group, it is related to social and learning problems. Second, the remaining two factors of influence having an effect with a common direction are two 
of the factors which, for the target group, were found to be not significant at one or two sites. It is still the case for one of them (entry level) but not so for the other (income), which turns out to be very significant at all three sites: socioeconomic background plays a greater role in the graduation of students using at home the dominant language of the site than in the graduation of those not using it.

Third and last, the remaining three variables lack an effect with a common direction influence, and they are the same variables for which the effect with a common direction on graduation of the target group was not consistently significant. Here, the direction of the effect displayed by these three variables can differ between sites, as it runs in the opposite way (to that substantiated for the target group) — once (for birthplace in Toronto and attendance at a socioeconomically challenged school in Vancouver) or even twice (for services in the language of instruction in Toronto and Vancouver).

\section{Multivariate analysis (II) : Participation in a selective or university-bound course}

We now shift from the first outcome indicator, representative of the students' academic performance, to the second indicator, representative of their educational pathways—or, more exactly, their aspirations for postsecondary education.

\section{Participation differences between the target and comparison groups}

As for the first indicator, we begin by examining whether the target group and its linguistic subgroups fare better than the comparison group. Again, this is done by isolating, from the estimated regression model, the impact of be-

Table 9. Odds of participation in selective/university-bound course: Odds ratios of target group(s) v. comparison group.

\begin{tabular}{|c|c|c|c|c|c|c|c|}
\hline \multirow{2}{*}{ Site } & \multirow{2}{*}{ Subgroup } & \multirow{2}{*}{$\begin{array}{l}\text { Global } \\
\text { odds } \\
\text { ratio }^{\mathrm{a}}\end{array}$} & \multirow{2}{*}{$\begin{array}{c}\begin{array}{c}\text { Models w/o } \\
\text { control }\end{array} \\
\text { Odds ratio }\end{array}$} & \multirow{2}{*}{$\begin{array}{c}\begin{array}{c}\text { Models w/ } \\
\text { control }\end{array} \\
\text { Odds ratio }\end{array}$} & \multicolumn{2}{|c|}{ Intraclass correlation } & \multirow{2}{*}{$\begin{array}{l}\text { \% of school } \\
\text { variance } \\
\text { explained } \\
\text { by model }\end{array}$} \\
\hline & & & & & $\begin{array}{l}\text { Empty } \\
\text { model }\end{array}$ & $\begin{array}{l}\text { Models w/ } \\
\text { control }\end{array}$ & \\
\hline \multirow{8}{*}{$\begin{array}{l}\text { Montreal } \\
(\mathrm{N}=9,360)\end{array}$} & Non French speakers & 1.16 & $1.61 * * *$ & $1.49 * * *$ & & $7.7 \%$ & $46.0 \%$ \\
\hline & Subgroups & & & & & $7.3 \%$ & $48.4 \%$ \\
\hline & Spanish & 0.57 & $0.77 * *$ & $0.70 * * *$ & & & \\
\hline & Arabic & 1.72 & $2.29 * * *$ & $1.96^{* * *}$ & & & \\
\hline & Creole & 0.14 & $0.26 * * *$ & $0.26 * * *$ & & & \\
\hline & Vietnamese & 3.77 & $3.41 * * *$ & $3.49 * * *$ & & & \\
\hline & Chinese & 4.31 & $5.90 * * *$ & $5.87 * * *$ & & & \\
\hline & Other non French speakers & n.c. & $1.53 * * *$ & $1.38 * * *$ & & & \\
\hline \multirow{9}{*}{$\begin{array}{l}\text { Toronto } \\
(\mathrm{N}=11,609)\end{array}$} & Non English speakers & 1.50 & $1.73 * * *$ & $1.82 * * *$ & & $20 \%$ & $4.8 \%$ \\
\hline & & & & & $21 \%$ & & \\
\hline & Subgroups & & & & & $20 \%$ & $4.8 \%$ \\
\hline & Chinese & 3.45 & $2.56 * * *$ & $2.86^{* * *}$ & & & \\
\hline & Tamil & 2.30 & $2.17 * * *$ & $2.32 * * *$ & & & \\
\hline & Urdu & 1.46 & $1.77 * * *$ & $1.83 * * *$ & & & \\
\hline & Russian & 1.64 & $1.37 * * *$ & $1.62 * * *$ & & & \\
\hline & Persian & 0.87 & 0.90 & $1.10 * * *$ & & & \\
\hline & Other non English speakers & n.c. & 0.99 & 0.97 & & & \\
\hline \multirow{9}{*}{$\begin{array}{l}\text { Vancouver } \\
(\mathrm{N}=21,450)\end{array}$} & Non English speakers & 3.27 & $3.54 * * *$ & $2.73 * * *$ & & $8.6 \%$ & $38.7 \%$ \\
\hline & & & & & $14.0 \%$ & & \\
\hline & Subgroups & & & & & $7.6 \%$ & $46.0 \%$ \\
\hline & Chinese & 8.50 & $11.19 * * *$ & $10.95 * * *$ & & & \\
\hline & Punjabi & 1.71 & $1.52 * * *$ & $1.63 * * *$ & & & \\
\hline & Vietnamese & 1.88 & $2.33 * * *$ & $3.13 * * *$ & & & \\
\hline & Tagalog & 1.63 & $1.52 * * *$ & $1.52 * * *$ & & & \\
\hline & Spanish & 0.55 & $0.65 * *$ & $0.71 * *$ & & & \\
\hline & Other non English speakers & n.c. & $2.13 * * *$ & $2.07 * * *$ & & & \\
\hline
\end{tabular}

Notes: $* * *$ Significant at $<0.001 ; * *$ Significant at $<0.05 ; *$ Significant at $<0.10 ;$ n.c. $=$ Not calculated.

${ }^{\text {a }}$ Calculated from corresponding participation rates. 
Ledent et al.: Academic performance and educational pathways of young allophones

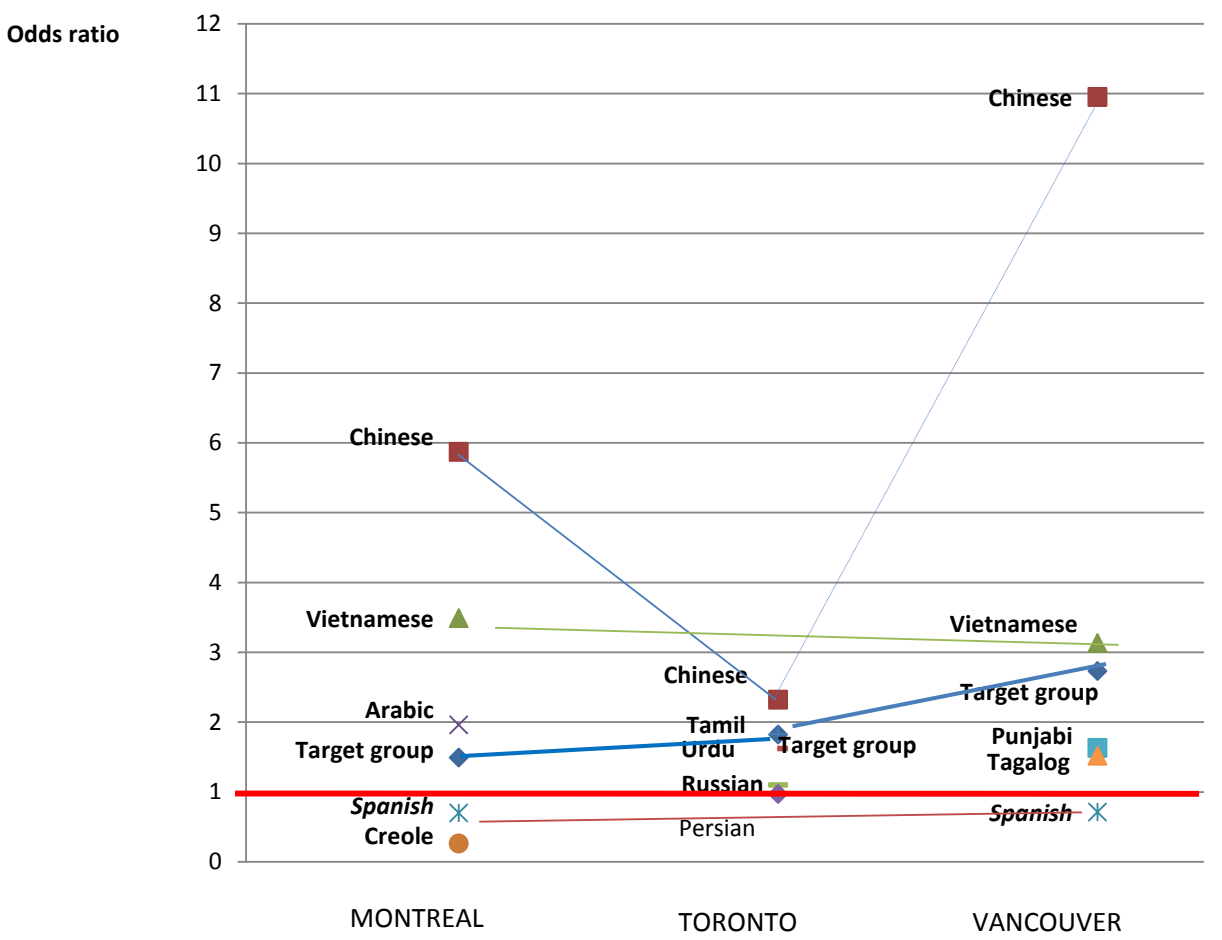

Figure 2. Odds of participation in a selective or university-bound course: Target group and its linguistic subgroups v. comparison group.

Note: subgroups significant at $<0.001$ are in bold, those significant at $<0.05$ are in bold italics, and those significant at $<0.1$ are in italics.

longing, first, to the target group, and second, to the various linguistic subgroups. However, this time the estimation is based not on the full student body but, rather to ensure that the analysis does not become a self-fulfilling prophecy, on the students who remained long enough in the school system to show a mark in any subject in Secondaire 5 in Montreal or in grade 12 at the other two sites.

As can be seen from the columns appearing in Table 9 under "Models w/control," the target group tends to participate in a selective or university-bound course more often than the comparison group. This is especially true in Vancouver, where the odds ratio of the former versus the latter reaches 2.73, versus 1.82 in Toronto and 1.49 in Montreal. Moreover, there are large differences between the various linguistic subgroups (also see Fig. 2), with the Chinese subgroup outdoing the other subgroups at all sites (with odds ratios of 5.87 in Montreal, 2.86 in Toronto, and 11.0 in Vancouver), the Spanish subgroup positioning itself below the speakers of the local dominant language in Montreal and Vancouver (with odds ratios equal to 0.70 and 0.71 , respectively), and the Creole subgroup clearly avoiding participation in Maths/Physics/Sciences in Montreal (with an odds ratio as low as 0.26).

Interestingly, comparison of the odds ratios obtained here with those previously obtained in the case of graduation leads to two discernible trends. First, the target group outperforms the comparison group more substantially with respect to participation than graduation in Toronto (1.82 v. 1.35) and Vancouver (2.73 v. 2.12) but not in Montreal (1.49 v. 1.39). Second, the range of variation between the five subgroups of the target group is substantially higher for participation than graduation in Montreal (22 v. 5 times) and Vancouver (15 v. 4 times) but somewhat less in Toronto (3 v. 2 times).

\section{Impact of factors on participation of the target group}

In comparison with the corresponding influence on graduation, the influence of the various factors on participation in a selective or university-bound course of the target group is clearly not as sharp (see Table 10). Indeed, only five of the nine factors act in the same direction. They include three of the four variables found to have a consistently significant effect on graduation (age at arrival, school change, and attendance in a private school), an effect that they still have here. ${ }^{20}$ They also include two of the variables found not to have a consistently significant effect, although in

20. Although the rather large impact of the private school variable in Vancouver is not statistically significant. 
Table 10. Odds of participation in selective/university-bound course: Impact of factors on target group.

\begin{tabular}{|c|c|c|c|c|c|}
\hline \multirow{2}{*}{ Type } & \multirow{2}{*}{ Variables (ref. value) } & \multirow{2}{*}{ Value } & $\begin{array}{l}\text { Montreal } \\
(\mathrm{N}=2,930)\end{array}$ & $\begin{array}{c}\text { Toronto } \\
(\mathrm{N}=3,333)\end{array}$ & $\begin{array}{l}\text { Vancouver } \\
(\mathrm{N}=8,175)\end{array}$ \\
\hline & & & Odds ratio & Odds ratio & Odds ratio \\
\hline \multirow{3}{*}{$\begin{array}{l}\text { Socio- } \\
\text { demographic } \\
\text { variables }\end{array}$} & Gender (Male) & Female & 0.91 & $1.47 * * *$ & 0.92 \\
\hline & Median family income & & $1.00 * *$ & $1.01^{* *}$ & $1.00 * *$ \\
\hline & Birthplace (Canada) & $\begin{array}{l}\text { Outside } \\
\text { Canada }\end{array}$ & $1.48 * * *$ & 0.81 & n.a. \\
\hline \multirow{4}{*}{$\begin{array}{l}\text { Schooling } \\
\text { process } \\
\text { variables }\end{array}$} & $\begin{array}{l}\text { Age upon entry (Early } \\
\text { / On time) }\end{array}$ & Late & $0.63 * * *$ & 0.65 & $0.50 * * *$ \\
\hline & Changed school (No) & Yes & $0.52 * * *$ & $0.44^{* * *}$ & $0.50 * * *$ \\
\hline & $\begin{array}{l}\text { Services in language } \\
\text { of instruction (No) }\end{array}$ & Yes & 1.48 & $0.45^{* * *}$ & 1.12 \\
\hline & $\begin{array}{l}\text { Entry level in } \\
\text { jurisdiction (Primary) }\end{array}$ & $\begin{array}{l}1 \text { st year of } \\
\text { secondary }\end{array}$ & $1.69^{*}$ & 1.20 & $1.48^{* * *}$ \\
\hline \multirow[t]{5}{*}{$\begin{array}{l}\text { School } \\
\text { context } \\
\text { variables }\end{array}$} & $\begin{array}{l}\text { Attendance at a } \\
\text { socioeconomically } \\
\text { challenged school in } \\
\text { public sector (No) }\end{array}$ & Yes & 1.17 & 0.76 & 0.64 \\
\hline & $\begin{array}{l}\text { Attendance at a } \\
\text { private school (No) }\end{array}$ & Yes & $2.47 * * *$ & n.a. & $2.28 * * *$ \\
\hline & Concentration of & $26-50 \%$ & 0.75 & 2.01 & $1.23 * *$ \\
\hline & target group in school & $51-75 \%$ & $0.61 *$ & 1.87 & 0.90 \\
\hline & attended $\quad(0-25 \%)$ & $76-100 \%$ & $0.61^{*}$ & $3.07 *$ & $0.69 * *$ \\
\hline \multicolumn{3}{|c|}{ Variance of random intercept s2u } & $0.32 * * *$ & $0.57 * * *$ & $0.45^{* * *}$ \\
\hline & $18.1 \%$ & $24 \%$ & $22.8 \%$ \\
\hline & & Intra-class correlation (full model) & $8.8 \%$ & $15 \%$ & $12.0 \%$ \\
\hline \multicolumn{3}{|c|}{ Percentage of school variance explained by model } & $51.5 \%$ & $37.5 \%$ & $47.3 \%$ \\
\hline
\end{tabular}

Notes: $* * *$ Significant at $<0.001 ; * *$ Significant at $<0.05 ; *$ Significant at $<0.10$. n.a. $=$ Not available.

a common direction, on graduation: entry level, which is now significant at two sites rather than just one, and income, which is highly significant at all three sites rather than just one.

Entry level is particularly remarkable, because its influence runs in the opposite direction to the one it had for graduation. Although arriving in the first year of secondary school (rather than in primary school) tends to reduce the likelihood of graduating, it increases the chances of continuing on to CEGEP/university. Another factor whose influence on participation is not the same as on graduation is gender. Whereas being a female (rather than a male) increases in a consistently significant manner the chances of graduating, it reduces the likelihood of participating in a selective or university-bound course, although not significantly, in both Montreal and Vancouver.

Finally, the three remaining factors, which were found to have a common but not always significant influence on graduation, display here an even more divergent pattern in the sense that in several instances they influence participation in the opposite direction, although not in a significant way: attendance at a socioeconomically challenged school in Montreal, birthplace in Toronto, and services in the language of instruction in both Montreal and Vancouver.

\section{Impact of factors on participation: Target versus comparison groups}

In the comparison group, it would appear that the factors of influence on resilience towards postsecondary education act in the same direction as for the target group, except for attendance at a socioeconomically challenged school in Montreal (see Table 11). Thus, as was the case for the target group, the direction of influence is not congruent at all three sites. Nevertheless, regardless of the direction of influence, all nine variables concerned have a significant influence at two of the sites: Toronto and Vancouver. In Montreal, it is the case for only six of them, be- 
Table 11. Participation in selective/university-bound course: Impact of factors on comparison group.

\begin{tabular}{|c|c|c|c|c|c|}
\hline \multirow[t]{2}{*}{ Type } & \multirow[t]{2}{*}{ Variables (ref. value) } & \multirow[t]{2}{*}{ Value } & $\begin{array}{c}\text { Montreal } \\
(\mathrm{N}=6,430)\end{array}$ & $\begin{array}{c}\text { Toronto } \\
(\mathrm{N}=8,276)\end{array}$ & $\begin{array}{c}\text { Vancouver } \\
(\mathrm{N}=13,275)\end{array}$ \\
\hline & & & Odds ratio & Odds ratio & Odds ratio \\
\hline \multirow{3}{*}{$\begin{array}{l}\text { Socio- } \\
\text { demographic } \\
\text { variables }\end{array}$} & Gender (Male) & Female & $0.90 *$ & $1.29 * * *$ & $0.84 * * *$ \\
\hline & Median family income & & $1.01 * * *$ & $1.01 * * *$ & $1.01 * * *$ \\
\hline & Birthplace (Canada) & $\begin{array}{l}\text { Outside } \\
\text { Canada }\end{array}$ & $1.70 * * *$ & $0.72 * * *$ & n.a. \\
\hline \multirow{4}{*}{$\begin{array}{l}\text { Schooling } \\
\text { process } \\
\text { variables }\end{array}$} & $\begin{array}{l}\text { Age upon entry (Early } \\
\text { / On time) }\end{array}$ & Late & $0.27 * * *$ & $0.38 * * *$ & $0.24 * * *$ \\
\hline & Changed school (No) & Yes & $0.35 * * *$ & $0.43 * * *$ & $0.59 * * *$ \\
\hline & $\begin{array}{l}\text { Services in language } \\
\text { of instruction (No) }\end{array}$ & Yes & 3.27 & $0.52 * * *$ & $1.45 * * *$ \\
\hline & $\begin{array}{l}\text { Entry level in } \\
\text { jurisdiction (Primary) }\end{array}$ & $\begin{array}{l}\text { 1st year of } \\
\text { secondary }\end{array}$ & 1.25 & $1.26 * * *$ & $2.46 * * *$ \\
\hline \multirow[t]{5}{*}{$\begin{array}{l}\text { School } \\
\text { context } \\
\text { variables }\end{array}$} & $\begin{array}{l}\text { Attendance at a } \\
\text { socioeconomically } \\
\text { challenged school in } \\
\text { public sector (No) }\end{array}$ & Yes & 0.79 & $0.49 * * *$ & $0.83 * * *$ \\
\hline & $\begin{array}{l}\text { Attendance at a } \\
\text { private school (No) }\end{array}$ & Yes & $1.79 * * *$ & n.a. & $3.09 * * *$ \\
\hline & Concentration of & $26-50 \%$ & 1.17 & $1.40 * *$ & $1.34 * * *$ \\
\hline & target group in school & $51-75 \%$ & 1.24 & $1.37 * *$ & 1.06 \\
\hline & attended $\quad(0-25 \%)$ & $76-100 \%$ & 1.90 & $2.29 * * *$ & 1.22 \\
\hline \multicolumn{3}{|c|}{ Variance of random intercept $\mathrm{s} 2 \mathrm{u}$} & $0.23 * * *$ & $0.86 * * *$ & $0.22 * * *$ \\
\hline \multicolumn{3}{|c|}{ Intra-class correlation (empty model) } & $12.2 \%$ & $20 \%$ & $9.3 \%$ \\
\hline \multicolumn{3}{|c|}{ Intra-class correlation (full model) } & $6.5 \%$ & $21 \%$ & $6.1 \%$ \\
\hline \multicolumn{3}{|c|}{ Percentage of school variance explained by model } & $46.2 \%$ & $0 \%$ & $34.0 \%$ \\
\hline
\end{tabular}

Notes: ***Significant at $<0.001 ; * *$ Significant at $<0.05$; $*$ Significant at $<0.10$ n.a. $=$ Not available.

cause two schooling process variables (services in the language of instruction and entry level) and one school context variable (attendance at a socioeconomically challenged school) turn out to be not significant.

\section{Conclusion: Policy implications}

What lessons can be learned about the academic performance and the educational pathways of immigrant youth at Canada's three main sites and the factors that influence them? Before providing some answers to this rather ambitious question, a few qualifications are needed. It is indeed very important to recall that although we can contrast trends and conclusions, there are too many differences between the three contexts to permit a strict comparison of both the characteristics of the various subgroups considered here and the indicators used to assess their educational experience. As stated earlier, there are significant variations in the structure of the school systems, the units studied, as well as the variables found in the data banks. In this last instance, the differences may concern the very availability of certain indicators (birthplace or attendance at a public or private school) or a slight variation in their definition. Nevertheless, the results bear enough resemblance to allow for some general comments that can, it is hoped, enlighten our understanding of the phenomenon under study, as well as point to some future directions for research.

A first observation emerging strongly from our study is the importance of subgroup differences in academic performance and educational pathways. By and large, the target group appears to succeed better than the comparison group, although it displays substantial outcome differences among subgroups, even after controlling for differences in individual characteristics. ${ }^{21}$ Specifically, those students who do not use their language of schooling at home tend to graduate from high school and participate in selective or university-bound programs more often than those who

21. These elements may be elucidated through qualitative research. 
do use it. But their outcomes vary widely among linguistic subgroups, with Chinese speakers appearing consistently on top and Spanish speakers ${ }^{22}$ as well as Portuguese speakers ${ }^{23}$ at the bottom. ${ }^{24}$ Such a result should not come as a surprise, for it is highly reminiscent of the findings in the recent literature on educational attainments and pathways that, based on the census and survey microdata now accessible in Statistics Canada's research date centres, relies on geographical or ethnic origin rather home language.

In a nutshell, this literature has shown, first, that persons with an immigrant background (first and second generations) who belong to the visible minorities have higher graduation rates in high school (as well as higher numbers of years of schooling) than those persons who do not, whether they have the same background (first and second generations) or, even more significantly, they are members of the third generation (Boyd 2002). Second, it has also shown that the children of immigrants (second generation) exhibit wide variations in university graduation rates by geographical origin. High for persons of East Asian, especially Chinese as well as other Asian origins, university graduation rates are low for black origins (Caribbean and sub-Saharan Africa) as well as some specific European origins such as Italian and Portuguese (Abada et al. 2009). Such variations, it would appear, stem from differences in parental education (Abada et al. 2009) as well as social capital (Abada and Tenkorang 2009).

Similarly, aspirations in postsecondary and especially university education are highest among the foreign-born who belong to the visible minorities and lowest among the Canadian-born who do not (Krahn and Taylor 2005). Moreover, rates of enrolment in university display wide variations that are similar to those already observed by others for university graduation: high for people with an East Asian origin and, to a lesser degree, another Asian origin and low for people with a Latin American or a black origin (Thiessen 2009). But separating black origins from Latin American origins shows that persons with an African origin are not too far below those with another Asian origin, whereas persons with a Latin American origin are way below, constituting in fact the only group positioned below the group of Canadian-born persons (Finnie and Mueller 2010).

Although a much more in-depth look at group differences is needed, the current findings should generate a common understanding within and across the various educational authorities on the way their services and programs for ESL/FSL or immigrant students are organized. Special attention should be paid to the criteria used to allocate special funds to schools with a high concentration of these target groups, or in some instances schools identified as socioeconomically challenged. It is obvious from our analysis that one size fits all support is not an evidence-based policy. Indeed, it does not take into account the fact that the allophone group, and in some instances, the schools in which it congregates, have a higher odd ratio of graduating than the comparison group, nor the wide variation across subgroups where one finds students four times more or less likely to graduate than the total student population.

A second observation coming out of our study relates to effects of the various factors of influence on the two dependent variables pertaining to the target group. In short, it would appear that they can be grouped in three categories, each comprising three variables. First, there are the factors that have a common and consistently significant impact on the two dependent variables: two schooling process variables (age on arrival and school change), as well as a school context variable (attendance at a private school). Second, there are the factors whose impact is more or less congruent between the three sites, although they affect the two dependent variables somewhat differently: in the same direction (income) but in opposite directions (gender and entry level). Third and last, the remaining factors (birthplace, services in the language of instruction and attendance at an economically challenged school) have a much less congruent influence but the impacts that tend to differ from the norm are never statistically significant.

22. For a good understanding of the educational problems affecting Spanish-speaking youth in Toronto, see Schugurensky et al. (2009) and Presley and Brown (2011).

23. Although Portuguese immigrants to Canada have, in spite of comparatively lower educational levels, achieved a certain measure of economic success and security, the Luso-Canadian community appears to have been marginalized in today's Canadian society. It is plagued by academic failure that is not being redressed by the practices and policies of the school system (Nunes 2004).

24. It remains that some linguistic groups perform differently across the three sites. This is especially the case of Vietnamese speakers, probably because, as suggested by a quick examination of the statistical profiles of the population with Vietnamese origin in the three cities, this community is better off in Montreal than in Toronto and, especially, Vancouver. Without a doubt, this can be attributed to the fact that the Vietnamese immigrants who settled in Montreal, before and after the end of the Vietnam War, were comparatively more educated (in French) than the immigrants, mostly refugees who came later on as part of the "boat people," and settled for the most part in Toronto and Vancouver. 
These latter differences between sites may be due to contextual differences. Indeed, the profile of 1st generation students in each site is different, there may be more importance of language instruction for school success in French in Montreal versus English in the other two cities, finally and the degree of economically challenged school may also vary across the sites.

In addition to the above observations directly related to the results of our multivariate analysis, other observations about the influence of some factors of influence are in order. For example, a significant gap in our understanding of the educational experience of immigrant youth concerns the impact of the socioeconomic status of their family. As seen earlier, our indicators in this regard are not adequate. However, even if individual data on students and their families become available, we would still need to explore this factor through alternative strategies. For example, one could ask whether there exists a threshold of basic revenue under which even extremely motivated immigrant parents cannot cope and continue supporting the positive school performance and schooling outcomes of their children? We should also better understand how SES interacts, positively or negatively, with other aggravating or mitigating factors linked to vulnerability or resilience.

Exploring the way in which the impact of various school factors actually materializes is also needed. In particular, it will disconcert strong proponents of public education to learn that even when the globally much more positive characteristics of their student body are accounted for, private schools, at least in Montreal and Vancouver where this data are available, seem to be doing a better job than public schools. Why is it so? To answer this question, we would first need to determine the extent to which other factors linked to the student body that were not taken into account in our study, such as learning skills, are at stake (it is well known that many private schools require entrance examinations). However, beyond that, if an advantage is still found, one would need to use qualitative methodology to identify the specific ethos of such schools that explains higher achievement among both majority and minority youth. The same type of analysis should be carried out within the public sector, where variance across schools with a rather similar intake of students is widespread.

\section{Acknowledgement}

This paper is based on a research project financially supported by the Canadian Council on Learning (CCL) and Citizenship and Immigration Canada (CIC); see Marie McAndrew (ed.), Educational Pathways and Academic Performance of Youth of Immigrant Origin: Comparing Montreal, Toronto and Vancouver, a report submitted to the Canadian Council on Learning and to Citizenship and Immigration Canada, May 2009 (http://www.chereum.umontreal.ca/publications_pdf/publications_pdf/CIC-CCL-Final12aout2009EN.pdf).

\section{References}

Abada, T., and E.Y. Tenkorang. 2009. Pursuit of university education among the children of immigrants in Canada: The roles of parental human capital and social capital. Journal of Youth Studies 12(2):185-207.

Abada, T., F. Hou, and B. Ram. 2009. Ethnic differences in educational attainment among the children of Canadian immigrants. Canadian Journal of Sociology 34(1):1-30.

Anisef, P., and K.M. Kilbride. 2001. To build on hope: Overcoming the challenges facing newcomer youth at risk in Ontario. Toronto: CERIS.

Anisef, P., M. McAndrew, J.G. Blais, C. Ungerleider, and R. Sweet. 2004. Academic performance and educational mobility of youth of immigrant origin in Canada: What can we learn from provincial data banks? Research Report. Immigration and Metropolis/CIC.

Beiser, M., F. Hou, I. Hyman, and M. Tousignant. 1998. Growing up Canadian: A study of new immigrant children (W-98-24E). Hull, QC: Human Resources and Development Canada.

Boyd, M. 2002. Educational attainments of immigrant offspring: Success or segmented assimilation? International Migration Review 36(4):1037-1060.

Bradley, R.H., and R.F. Corwin. 2002. Socio-economic status and child development. Annual Review of Psychology 53:371-399. 
Bussière, P., F. Cartwright, T. Knighton, and T. Rogers. 2004. Measuring up: Canadian results of the OECD PIS A Study: The Performance of Canada's Youth in Mathematics, Reading, Science, and Problem Solving - 2003 First Findings for Canadians Aged 15. Ottawa: Human Resources and Skills Development Canada, Council of Ministers of Education, and Statistics Canada.

Chamot, A., and M. O’Malley. 1994. The Calla Handbook. Reading, MA: Addison-Wesley.

Chow, H. 2004. The effects of ethnic capital and family background on school performance: A case study of Chinese-Canadian adolescents in Calgary. Alberta Journal of Educational Research 50(3) [electronic version].

CIC (Citizenship and Immigration Canada). 2011. Immigration overview: Permanent and temporary residents. Facts and figures 2010 series. http://www.cic.gc.ca/english/resources/statistics/menu-fact.asp (accessed April 19, 2012).

CMEC (Council of Ministers of Education Canada). 2003. Education indicators in Canada: Report of the panCanadian education indicators program. Catalogue No. 81-582-XIE. Ottawa, ON: Statistics Canada. http:// www.statcan.gc.ca/pub/81-582-x/2003001/4148918-eng.htm (accessed on April 19, 2012).

Collier, V. 1989. How long? A synthesis of research on academic achievement in a second language. TESOL Quarterly 23(3):509-531.

Corak, M. 2011. Age at immigration and the educational outcomes of children. Analytical Studies Research Paper Series (Catalogue no. 11F0019M - No. 336). Ottawa: Statistics Canada.

Crahay, M. 2000. Les défis de l'école démocratique, in L'école pent-elle être juste et efficace? De l'égalité des chances à l'égalité des acquis, edited by M. Crahay. Paris: De Boeck, pp. 48-82.

Cummins, J. 2000. Language, Power and Pedagogy: Bilingual Children Canght in the Crossfire. Toronto: Multilingual Matters.

Dei, G. 1996. Antiracist Education: Theory and Practice. Halifax, NS: Fernwood Publishing.

Duff, P. 2001. Language literacy and content and (pop) culture: Challenges for ESL students in mainstream courses. The Canadian Modern Language Review 58(1) [electronic version].

Finnie, R., and R.E. Mueller. 2010. They came, they saw, they enrolled: Access to postsecondary education by the children of Canadian immigrants, in Pursuing Higher Education in Canada: Economic, Social and Policy Dimension, edited by R. Finnie, M. Frenette, R.E. Mueller, and A. Sweetman. Montreal-Kingston: McGill-Queen's University Press, pp. 191-216.

Gillborn, D., and C. Gipps. 1996. Recent Research on the Achievements of Ethnic Minority Pupils. London: Office for Standards in Education.

Haveman, R., and B. Wolfe. 1994. Succeeding Generations: On the Effects of Investments in Children. New York: Russell Sage Foundation.

Johnson, J., and R. Acera 1999. Hope for urban education: A study of nine high-performing, high-poverty urban elementary schools. Report of Method to the US Department of Education, Planning and Evaluation Services, The Charles A. Dana Center, University of Texas at Austin.

Kazemipur, A., and S.S. Halli, 2001. Immigrants and "New Poverty:" The Case of Canada. International Migration Review 35(4):1129-1156.

Krahn, H., and A. Taylor. 2005. Resilient teenagers: Explaining the high educational aspirations of visible-minority youth in Canada. Journal of International Migration and Integration 6(3-4):405-434.

Marks, G. 2005. Accounting for immigrant non-immigrant differences in reading and mathematics in twenty countries. Ethnic and Racial Studies 28(5):925-946.

McAndrew, M. 2001. Immigration et diversité à l'école: le débat québécois dans une perspective comparative. Montreal: Presses de l’Université de Montreal. 
McAndrew, M. 2004. Immigration, pluralism and education, in Québec: State and Society, edited by A. Gagnon. 3rd edn. Peterborough, ON: Broadview Press, pp. 307-328.

McAndrew, M., and C. Cicéri (with the collaboration of P. Lamarre and A. Varma). 1997. The Role of the Education in the Integration of Immigrants: Current Research and Future Perspectives. Proceedings of the Seminar in Education, Metropolis Project, St. John's, NL, June 13. Montreal: Immigration et métropoles.

McAndrew, M., B. Garnett, J. Ledent, and R. Sweet, with the collaboration of H. Ben Salah and A. Balde. 2011. Les carrières scolaires des jeunes allophones à Montréal, Toronto et Vancouver: une analyse comparative. Journal of International Migration and Integration / Revue de l'immigration internationale et de l'intégration 12(4):495-515.

McEwen, N. (ed.). 1995. Accountability in education in Canada. Special issue, Canadian Journal of Education 20(1).

Nunes, F. 2004. Portuguese-Canadian youth and their academic underachievement: A literature review. PortugueseStudies Review 11(2):41-87.

OECD. 2006. Where Immigrant Students Succeed: A Comparative Review of Performance and Engagement in PIS A 2003. Paris: OECD.

Ogbu, J.U. 1992. Adaptation to minority status and impact on school success. Theory into Practice 31(4):287.

Ogbu, J., and H. Simmons. 1998. Voluntary and involuntary minorities: A cultural-ecological theory of school performance with some implications for education. Anthropology and Educational Quarterly 29:155-188.

Peng, S.S., and D. Wright. 1994. Explanation of academic achievement of Asian American students. Journal of Educational Research 87(6):346-352.

Picot, G., and F. Hou. 2003. The rise in low income rates among immigrants in Canada. Analytical Studies Branch Research Paper Series (Catalogue no. 11F0019MIE, No. 198). Ottawa: Statistics Canada.

Portes, A. 1994. The new second generation. International Migration Review 28:108.

Portes, A., and M. Zhou. 1993. The new second generation: Segmented assimilation and its variants. Annals of the American Academy of Political and Social Science 530:74-96.

Presley, A., and R.S. Brown. 2011. Portuguese-speaking students in the TDSB: An overview. Report No. 11/12-01. Toronto: Toronto District School Board.

Samuel, E., E. Krugly-Smolska, and W. Warren. 2001. Academic achievement of adolescents from selected ethnocultural groups in Canada. McGill Journal of Education 36(1):61-73.

SAS. 2008. SAS/STAT. 9.1 User's Guide: The MIXED Procedure. Cary, NC: SAS Institute Inc.

Schermerhorn, R.A. 1970. Comparative Ethnic Relations: A Framework for Theory and Research. New York: Random House.

Schugurensky, D., D. Mantilla, and J.F. Serrano (eds.). 2009. Four in ten: Spanish-speaking youth and early school leaving in Toronto. Published by the Latin American Research Education and Development Network (LARED) and the Transformative Learning Centre, Ontario Institute for Studies in Education of the University of Toronto (OISE/UT).

Statistics Canada. 2008. Education Reference Guide, 2006 Census. Catalogue no. 97-560-GWE2006003. Ottawa: Statistics Canada. http://www12.statcan.gc.ca/census-recensement/2006/ref/rp-guides/education-eng.cfm (accessed on April 19, 2012).

Thiessen, V. 2009. The pursuit of post-secondary education: A comparison of First Nations, African, Asian, and European Canadian youth. Canadian Review of Sociology 46(1):5-37.

Toronto Board of Education. 1999. A Study of the Grade Nine Cohort of 1993, 1993-1998: The last grade nine cohort of the Toronto Board of Education. Research Report No. 229. Toronto: Toronto District School Board.

Vallet, L.A., and J.P. Caillé. 1996. Les élèves étrangers ou issus de l'immigration: les résultats du panel français dans une perspective comparative. Migrants et formation 104:66-86. 
Zady, M., and P. Portes. 2001. When low SES parents cannot assist their children in solving science problems. Journal of Education for Students Placed at Risk 6(3):215-229.

Zhou, M., and C.L. Bankston III. 2001. Family pressure and the educational experience of the daughters of Vietnamese refugees. International Migration 39(4):133-151.

Zhou, M., and J. Lee. 2007. Becoming ethnic or becoming American? Reflecting on the divergent pathways to social mobility and assimilation among the new second generation. Du Bois Review 4(1):189-205. 